Aksaray University
Journal of Science and Engineering
e-ISSN: 2587-1277
http://dergipark.gov.tr/asujse
http://asujse.aksaray.edu.tr

Research Article

\title{
Social Housing Production in Terms of Constructive Demolition and Quality of Life: The Example of Istanbul
}

\author{
Alper Bodur*, Yurdanur Dulgeroglu Yuksel \\ Istanbul Technical University, Faculty of Architecture, Department of Architecture, Istanbul, 34437, Turkey \\ -Received Date: 13 Mar 2017 \\ -Revised Date: 16 May 2017 \\ -Accepted Date: 17 May 2017 \\ -Published Online: 18 May 2017
}

\begin{abstract}
There are widely different characteristics in the literature, as well as common features related to the concept of quality of life. In urban life, the quality of life is determined by the interaction of social, economic and physical environment and is directly related to the practices of central and local decision makers. Today, through the state and municipalities, social housing is being produced to solve low-income families' housing problems and to improve the quality of life in general. The purpose of this study is to investigate the effect of the housing production based on the slum dwelling on the quality of life of households. A total of 506 surveys were conducted in 3 districts to assess the quality of life of residents in İstanbul. Accordingly, living situation (individual well-being, quality of life), physical (housing, shelter), environment (habitat, urban infrastructure), social (neighbourhood relations, family relations), economic (business, employment, income, indebtedness), access to services (transportation, municipal services) and 7 indicators, including general factors of life quality were identified. As a result of this study, the improvement of the quality of life of displaced slum dwellers and the improvement of the communication and communication ways of slum dwellers and decision makers are proposed.
\end{abstract}

\section{Keywords}

Social Housing, Gecekondu, Life Quality

"Corresponding Author: Alper BODUR, boduralper@yandex.com 


Aksaray University
Journal of Science and Engineering
e-ISSN: 2587-1277
http://dergipark.gov.tr/asujse
http://asujse.aksaray.edu.tr

Research Article

\title{
Yapıcı Yıkım Olması Bakımından Sosyal Konut Üretimi ve Yaşam Kalitesi: İstanbul Örneği
}

\author{
Alper Bodur*, Yurdanur Dülgeroğlu Yüksel \\ İstanbul Teknik Üniversitesi, Mimarlık Fakültesi, Mimarlık Bölümü, İstanbul, 34437, Türkiye \\ -Gönderi Tarihi: 13 Mar $2017 \quad$-Düzeltme Tarihi: 16 May $2017 \quad$ •Kabul Tarihi: 17 May $2017 \quad$-Çevrimiçi Yayın Tarihi: 18 May 2017
}

\section{Özet}

Yaşam kalitesi birey ve toplum ile ilişkili olduğu kadar sosyal, ekonomik ve fiziki çevre ile de ilişkilidir. Şehir hayatında, yaşam kalitesi sosyal, ekonomik ve fiziksel çevrenin etkileşimi ile belirlenmekte olup doğrudan merkezi ve yerel karar vericilerin uygulamaları ile ilişkilidir. Varlık nedeni yerel nitelikteki hizmetlerin karşılanması olan belediyelerin kentlerde yaşayan nüfusa hizmetlerinde önemli sorumluluklar bulunmakta, ancak bunları yerine getirmekte yetersiz kaldıkları görülmektedir. Günümüzde devlet ve belediyeler aracılığıyla düşük gelirli ailelerin konut sorunlarına çözüm bulmak ve genel olarak kentin yaşam kalitesini yükseltmek için sosyal konutlar üretilmektedir. Bu makale, İstanbul'da gecekondusu tasfiye olan sosyal konut sakinlerinin yeni sosyal konutlarına nasil adapte olduklarını değerlendiren bir çalışmanın sonucudur. Gecekondularda yaşayan ve sosyal konuta taşınanların yaşam kalitesinde ortaya çıkan değişim, İstanbul Büyükşehir Belediyesi’nin ürettiği sosyal konutlarda geniş bir örnekleme ile araştırılmıştır. Konut sakinlerinin yaşam kalitelerini değerlendirmek için, toplamda 3 ilçede 506 adet anket gerçekleştirilmiştir. Bu kapsamda, (1) yaşam durumu, (2) fiziksel faktörler, (3) çevresel faktörler, (4) sosyal ilişkilere yönelik karşılaştırmalar, (5) hizmetlere erişim, (6) ekonomik faktörler, (7) genele yönelik memnuniyet başlıklarından oluşan 7 temel gösterge belirlenmiştir. Bu çalışmanın sonucu olarak, yer değiştiren gecekondu sakinlerinin yaşam kalitesinin yükseltilmesi için gecekondu sakinlerinin ve karar vericilerin birlikte çalışması ve iletişim yollarının iyileştirilmesi öncelikle önerilmektedir.

\section{Anahtar Kelimeler}

Sosyal Konut, Gecekondu, Yaşam Kalitesi

*Sorumlu Yazar: Alper BODUR, boduralper@yandex.com 


\section{GIRIŞ̧}

Konut yalnızca fiziksel bir barınak olmaktan ziyade, aynı zamanda konut ve konutu çevreleyen ortamla birlikte bir kişinin fiziksel, zihinsel ve duygusal sağlık koşulları açısından önemli bir rol oynamaktadır [1]. Bugün, yaşam koşullarının değişmesi halkın beklentilerini ve önceliklerini değiştirmiştir. Ekonomik büyümenin ve farklılıkların bir arada bulunduğu bu postmodern küreselleşmiş çağda, insanların refahı ve yaşam kalitesi araştırmaları daha önemli hale gelmiştir [2].

Gecekondu tasfiyesi ve sonrasında yeniden yerleşim projeleri giderek dünyadaki günlük yaşamın bir özelliği haline gelmiştir. Gecekondulardan yeni evlere taşınma gecekondu sakinleri için kolay değildir [3]. Gecekondu sakinlerinin yaşamlarını iyileştirmek, yoksulluğun sona erdirilmesi için vazgeçilmez araçlardan biri olarak kabul edilmektedir [4]. Toplumsal sorunlar, farklılıklar, refah ve yaşam kalitesi, post-modern çağın coğrafi araştırmalarının yeni alanlarındandır. Yaşam kalitesi çalışmaları, toplumun ve ülkelerin gelişimi için daha uygun hale gelmektedir [2].

1960'lı ve 1970'li yıllarda, Dünya Bankası ve daha sonra UN Habitat gibi uluslararası kuruluşlar kentsel gelişim hedeflerini konut ve temel hizmetleri iyileştirmeye odaklamışlardır [4]. Yirminci yüzyılın başından itibaren kentin hızlı ve genellikle kontrolsüz gelişimi, yalnızca doğayı işlevsiz duruma getirmekle kalmamış, aynı zamanda bireylerin yaşam kalitesinin bozulmasına neden olmuştur [5].

Uluslararası literatürde uzun zamandır incelenen bir alan olmasına karşın, yaşam kalitesi Türkiye açısından yeni sayılabilecek bir araştırma alanıdır [6]. Bu nedenle yaşam kalitesi çalışmaları, kamu yöneticileri ve yerel yöneticiler için son derece önemlidir [7].

Son yıllarda, çeşitli devlet kuruluşları kentsel yoksulların yer değiştirme projeleriyle ilgilenmektedir [8]. Varlık nedeni yerel nitelikteki hizmetlerin karşılanması olan belediyelerin kentlerde yaşayan nüfusa hizmetlerinde önemli sorumluluklar bulunmaktadır. Belediyeler gün geçtikçe artan görev ve sorumluluklarına karşılık, görev ve sorumluluklarını yerine getirmekte yetersiz kalmakta, kent hizmetlerinin çeşitlenmesi ve taleplerin artmasına karşılık hizmetlerin etkin ve verimli olarak sunulamaması kentsel yaşam kalitesini olumsuz yönde etkilemektedir [9-10].

Bu çalışma kapsamında, İstanbul Büyükşehir Belediyesi tarafından üretilen sosyal konutlardaki durumu açıklamak, gelişmiş ülkelerde ve uluslararası kuruluşlarca yapılan çalışmalar açısından durumu ele alarak, İstanbul'da yapılmış çalışmaları irdelemek ve yapılabilecekleri açıklamak hedeflenmektedir. $\mathrm{Bu}$ çalışmada, İstanbul Büyükşehir Belediyesi Mesken Müdürlüğü 
tarafından üretilen sosyal konut uygulaması öncesinde ve sonrasında ev halkının hayatının nasıl değiştiği incelenmiştir. Yaşam kalitesi göstergeleri belirlenerek yaşam kalitesiyle sosyal konut politikaları arasındaki ilişkinin bir analizi yapılmıştır.

\section{YAŞAM KALITESİ KAVRAMI}

Yaşam kalitesi kırk yılı aşkın bir süredir araştırılmaktadır. Bugünkü anlamıyla yaşam kalitesine ilişkin araştırmalar, 1960'larda ABD'de oluşan sosyal göstergeler hareketine dayanmaktadır [11]. Yaşam kalitesi kavramının, toplumda yaşam koşullarındaki farklılık ve eşitsizlikler ile sosyal koşulların araştırılması amacıyla ortaya çıktığı belirtilmektedir [12].

Çeşitli ihtiyaçlar, zorluklar ve engeller nedeniyle aileler yaşam kalitelerini etkileyen koşullarla karşılaşabilmektedir [13]. Kişilerin daha iyi yaşam standardına kavuşturulması ve refah düzeyinin arttırılması gerekliliğinin, 2. Dünya Savaşı sonunda yaşanan yeniden yapılanma sürecinde gündeme gelmesinin ardından yaşam kalitesi araştırmaları önem kazanmıştır [14]. Yaşam kalitesi araştırmaları, daha önceleri yapıldığı gibi bir kentin ekonomik durumuna göre sıralamasını içermekten çok öteye geçmiştir [2].

Farklı disiplinlerde yaşam kalitesini tanımlamak için birçok girişimde bulunulmuştur. Literatürde yüzden fazla tanımı bulunmaktadır [15]. Kötü koşullarda, yaşam kalitesi tanımlanırken; iş, gıda, barınma ve güvenlik olanakları gibi temel ihtiyaçlara odaklanılmaktadır. Buna karşılık iyi koşullarda yaşam kalitesi tanımı eğlence ve rekreasyon olanaklarına erişimi, mutlu bir toplumu, temiz bir çevreyi ve başarılı kişisel ve mesleki hayatı içerecek şekilde genişlemektedir [16].

Diğer yandan, yapılan araştırmalarda yaşam kalitesi, farklı amaç ve hedefler doğrultusunda, farklı yöntemlerle ölçülmekte ve araştırma ölçekleri de bu doğrultuda birbirinden farklılık göstermektedir [17-22]. Yaşam kalitesinin ölçülmesinde kullanılacak göstergelerin türü ve kriterleri konusunda da uzlaşma bulunmamaktadır [7-23]. Yaşam kalitesi ile ilgili faktörler kentlere, kültürlere, şartlara göre ve zaman içinde değişebilmektedir [11]. Son yıllarda kentsel yaşam kalitesi araştırmaları gelişmiş ülkelerde hızla artmakta iken gelişmekte olan ülkelerde daha yavaş ilerlemektedir. Türkiye'deki yaşam kalitesi çalışmaları Batı ile eşzamanlı olarak başlayamamış ve aynı hızda ilerleyememiştir [7].

Türkiye' de yaşam kalitesi kavramı beş yıllık kalkınma planlarında da yer almaktadır. Kentlerde nüfusun hızlı artışıyla bağlantılı olarak Onuncu Beş Yıllık Kalkınma Planı döneminde (20142018) şehirleşme, nüfus artışı, yenileme ve afetten kaynaklanan konut ihtiyacının toplam 4.1 milyon olacağı tahmin edildiğinden, afet riski taşıyan alanlar başta olmak üzere üretim ve ortak kullanım alanlarında yüksek fayda ve değer üreten, büyüme ve kalkınmaya katkı sağlayan, 
mekân ve yaşam kalitesini yaygın şekilde artıran dönüşüm projelerine öncelik verileceğinden bahsedilmektedir [24].

Fakat kalkınma planlarıyla konut sorununa ilişkin olarak getirilen ilkeler, politikalar ve tedbirler yeterince uygulanamamış, şehirleşme hızı ile birlikte sorunlar da giderek artmıştır [25]. Türkiye'de yaşam kalitesi ile ilgili çalışmaların sayısının günümüzde artmasına rağmen hala yetersiz olduğu söylenebilir.

\section{GECEKONDU TASFIYESI BAĞLAMINDA SOSYAL KONUT ÜRETIMİ}

Birinci Dünya Savaşı'ndan sonra ortaya çıkan konut sıkıntısı ilk defa devletleri konut sorununun çözümü konusunda düşünmeye zorlamıştır. Ancak Batı'da devlet, 2. Dünya Savaşı'ndan sonra geliştirilen ve 1980'li yıllara kadar uygulanan sosyal konut politikalarıyla konut üretimine bizzat katılarak veya yerel yönetimleri destekleyerek sorunun çözümü konusunda aktif rol oynamıştır [26].

Köyden kente göçün olduğu ülkelerde farklı isimler altında karşılaşılan gecekondu olgusu, 1950'den sonra barınma amacıyla yapılmış olmasıyla beraber sosyal, kültürel, ekonomik ve çevresel etkileriyle de önem taşıyan bir konu haline gelmiştir. Ancak, gecekondu ve gecekonduluların sorunlarının çözümü konusunda inşaatı kadar hızlı ve etkin politikalar geliştirilememiştir. Başlangıçta, yapı malzemesi ve yapım özellikleriyle fizikî bir mekân tanımı olarak kullanılan gecekondu kavramı, zamanla bir yaşam biçimini nitelendiren içeriğiyle, sosyolojik bir anlam kazanmıştır [27].

Gecekondulaşma, yetersiz konut koşullarını da beraberinde getirmektedir. Özellikle yeterli su kaynaklarının olmaması, atık uzaklaştırma ve alt yapı yetersizlikleri, sağlı bakım hizmetlerinden yararlanamama ve ulaşılabilir bir sağlık hizmetinin bulunmaması, eğitim koşullarının yetersizliği en önemli sorunları oluşturmaktadır [28-30].

Gelişmiş ülkeler 2. Dünya Savaşı'ndan sonra uygulamaya koydukları sosyal konut politikalarıyla, konut sorununu önemli ölçüde çözmüşlerdir [31]. 2. Dünya Savaşı sonrası otuz yıl için sosyal konutun altın çağı denilebilir. En fazla sosyal konut bu süreçte üretilmiştir [32]. Diğer yandan, dar gelirlilere yönelik üretilen konutların sayısı, dünya genelinde gelişmiş ve gelişmekte olan ülkelerde önemli sorunlardan biri olmaya devam etmektedir [13-26].

Sosyal konutlar, batılı gelişmiş ülkelerde orta ve dar gelirli kentlilere yönelik ucuz kiralık konutlar şeklinde ortaya çıkarken, gelişmekte olan ülkelerde ağırlıklı olarak kiralama değil konutların satışı söz konusu olmakta, bunlar düşük faizli ve uzun vadeli toplu konut kredileriyle gerçekleşmektedir. Gelişmiş ülkelerde, belediyeler, konut birlikleri üzerinden sosyal konut 
uygulamaları yürütülürken, gelişmekte olan ülkelerde bu uygulamalar merkezi yönetimler tarafından yürütülmektedir [33].

Avrupa'da sosyal konutların yapımları farklı birçok kurum tarafından gerçekleşmektedir. Bunlardan bazıları merkezi ve yerel yönetimler, kar amacı gütmeyen kamusal veya özel kuruluşlar, gönüllü kurum veya vakıflar, kooperatifler ve kar amacı gütmeyen özel sektör kuruluşlarıdır. Böylece sosyal konutlar ülke içerisindeki farklı kurumlara ait olabilmektedir [34]. Avrupa'da sosyal konutun normal ya da standart olması ile ilgili karar vermek, oldukça zor görünmektedir [35].

Whitehead ve Scanlon'a göre [36] gelişmiş ülkelerdeki sosyal konut uygulamalarında ortak yönler bulunmakla beraber, her bir ülkede aynı şekilde geçerli olan standart bir sosyal konut uygulama ve politikası söz konusu olmamıştır [36]. Bazı ülkelerde toplumun yalnızca en yoksul kesimi bu konutlardan yararlanabilirken, bazı ülkelerde düşük ücretli kesimler, bazı ülkelerde de orta gelir düzeyine sahip kesimler de bu konutlardan yararlanabilmektedir [33-37].

Gelişmekte olan ülkelerin sosyal politikalarının bir parçası olarak sosyal konut faaliyetlerine girmeleri 1980'lerden itibaren tedricen başlamış ve her bir ülke için farklı gelişim seyirleri izlenmiştir [33].

Avrupa ve Amerika'da planlama yaklaşımlarının ve yöntemlerinin geçirdiği evrimin Türkiye’ye yansımasının olumlu olduğu söylenemez [38]. Avrupa ülkelerinde kentsel dönüşüm faaliyetleri daha çok ekonomik ömrünü tüketmiş çöküntü alanlarında uygulanırken ülkemizde kentsel dönüşüm faaliyetlerinin en önemli ayağını gecekondu dönüşümü oluşturmaktadır [31]. Şekil 1'de Kâğıthane İlçesi'nde bir gecekondu gösterilmektedir. Türkiye'de özellikle Avrupa ülkelerinde olduğu gibi sosyal konut anlamında sistemli bir kamu politikasından söz etmek mümkün değildir [39-40].

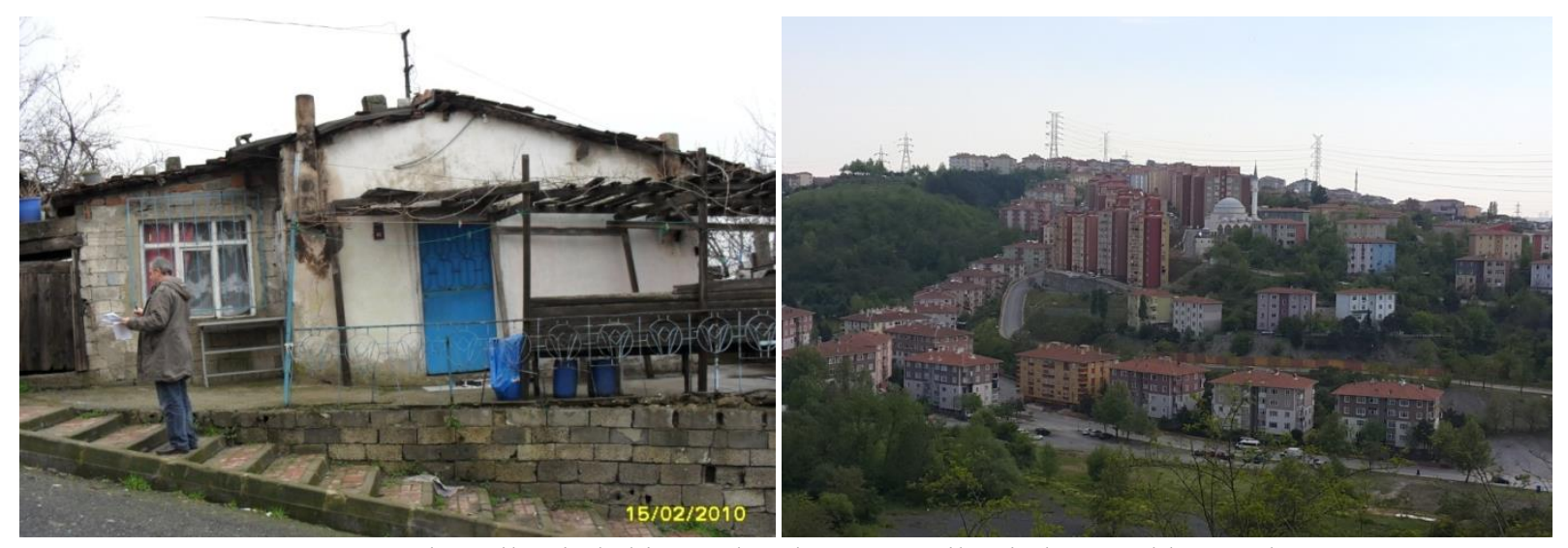

Şekil 1. Kâğıthane ilçesinde bir gecekondu ve Eyüp ilçesinde sosyal konut alanı 
2003 yılından günümüze gelinceye kadar, Türkiye'de konut politikalarındaki sorumlu aktörlerde önemli değişiklikler olmuş ve bunların sonucu olarak günümüzde TOKİ, ülkedeki konut politikalarında en yetkili kurum haline gelmiştir. Bugün TOKİ, Türkiye'nin her ilinde ve yurtdışında, başta konut olmak üzere çok sayıda yapı üretimi gerçekleştirmeye devam etmektedir [41-42].

Büyükşehir belediyeleri konut üretimi konusunda son yıllarda çok önemli bir aktör haline gelmiştir [26]. Bu kapsamda, İstanbul Büyükşsehir Belediyesine bağlı olarak faaliyetlerine devam eden Mesken Müdürlüğü çalışmaları dikkat çekmektedir. İstanbul Büyükşehir Belediyesi Mesken Müdürlüğü faaliyetleri, her yıl düzenli bir şekilde rapor haline getirilerek üst makamlara ulaştırılmaktadır. 2013 yılı faaliyet raporunda, müdürlüğün vizyonunun dört temel unsuru; İstanbul'un eşsiz mirasına sahip çıkılması, yaşam kalitesinin yükseltilmesi, kentin sürdürülebilir bir dünya kenti olması, belediyecilik hizmetlerinin öncü ve önder belediye kimliği ile yürütülmesi olarak ifade edilmiştir [43].

Mesken Müdürlüğü, gecekondu sahiplerine sosyal konut tahsisi yaparken, elde mevcut ve tahsise hazır olan sosyal konutları tahsis etmekte, bu süreçte ise farklı ilçedeki bir sosyal konuta tahsis yapılabilmektedir. 1988-2013 yılları arasında Eyüp'te yapılan sosyal konutlara taşınma Şekil 2'de gösterilmektedir. Eyüp ilçesinde üretilen sosyal konutlarda, birçok ilçeden taşınan insanlar bulunmaktadır. Mavi ile işaretli olan noktalar sosyal konut alanları iken, mor renkli olan noktalar ise gecekondu alanlarıdır.

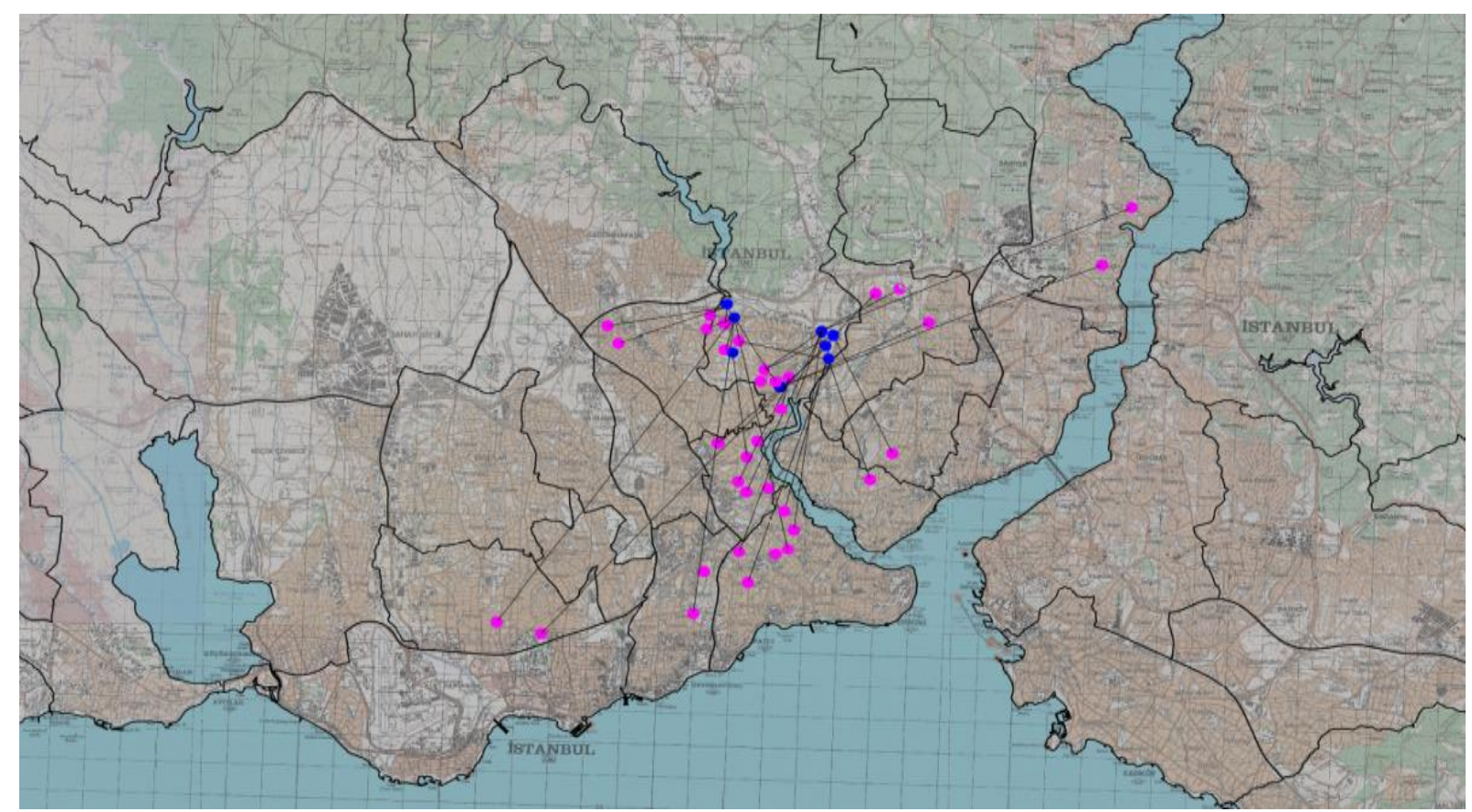

Şekil 2. Eyüp’te yapılan sosyal konutlara taşınma süreci harita gösterimi 
Mesken Müdürlüğü faaliyetleri Tablo 1'de gösterilmektedir. Buna göre, 1988-2013 yılları arasında, 25 yıl içerisinde yaklaşık 465 adet projede 4606 adet gecekondu tasfiye edilmiş, yaklaşık 10638 adet konut üretimi gerçekleştirilmiştir. Üretilen yaklaşık 10638 adet konuttan yaklaşık 3381 adedi gecekondu sahiplerine tahsis edilmiştir.

Tablo 1. 1988-2013 arası İ.B.B. Mesken Müdürlüğü faaliyetleri

\begin{tabular}{lr}
\hline Faaliyet & Toplam \\
\hline Gerçekleşen Proje Adedi & 465 \\
Yıkılan Gecekondu Adedi (Bina) & 4606 \\
Tahsis Yapılan Sosyal Konut Adedi & 3381 \\
Tamamlanan Sosyal Konut Adedi & 10638 \\
Tamamlanan Kat Karşılığı Konut Adedi & 2020 \\
Tamamlanan Sosyal Donatı Proje Adedi & 57 \\
\hline
\end{tabular}

\section{METODOLOJİ}

Araştırmanın evrenini, İstanbul Büyükşsehir Belediyesinin gecekondu sahipleri için ürettiği konut çalışmaları kapsamında, İstanbul ili sınırlarında gecekondu sakinlerinin 775 sayılı yasa çerçevesinde gecekondularının tasfiye edilmesiyle üretilen sosyal konutlara taşınan gecekondu sakinleri oluşturmaktadır. Araştırmanın örneklemi, evrenden elde edilen veriler sonucunda oluşturulmuş̧tur.

İstanbul Büyükşehir Belediyesi Mesken Müdürlüğü tarafından birçok ilçede sosyal konut üretimi gerçekleştirilmiştir. Konut sayısı açısından bakıldığında en fazla sosyal konut üretimi sırasıyla Pendik, Eyüp, Güngören, Kâğıthane, Kartal, Esenler, Şişli ve diğer ilçeler şeklindedir. Gecekonduları başka bir ilçede veya uzak alanlarda tasfiyeye uğramış ve farklı bir ilçeye ya da İstanbul içerisinde olsa dahi farklı bir kültürel yapıya ayak uydurmak zorunda olan insanlara yönelik üretilen sosyal konutların en fazla oranda Eyüp, Şişli ve Kartal'da üretilen sosyal konutlar olduğu ortaya çıkmıştır. Bu sebeple, Eyüp, Kartal ve Şişli ilçelerinde yapılan sosyal konutlar örneklem alanı olarak belirlenmiştir.

$\mathrm{Bu}$ araştırmada küme örneklemesi temelinde rastlantısal örnekleme tekniği kullanılmıştır. Küme örnekleme tekniği, evreni oluşturan birimlerin tam bir listesinin elde edilemediği durumlarda sıklıkla başvurulan bir tekniktir [44].

Araştırma modeliyle birlikte anket soruları oluşturulmuş, pilot anket çalışması tamamlanarak sorular nihai haline getirilmiş ve toplam 506 adet hane halkı ile görüşme yapılmıştır. Başından 
itibaren anketle ilgili yapılan çalışmalarda toplamda 21 adet düzeltme yapılmış ve 26 Şubat 2016 tarihinde anket nihai şeklini almıştır.

Bu çalışmada kullanılacak gösterge setinin oluşturulmasında, literatürde farklı bakış açıları ve farklı yaklaşımlara göre pek çok tanımı yapılan yaşam kalitesi kavramı ile ilgili, kavramın sınırlarının zorlanarak anlam bozulmalarına yol açmamak ve anlaşılabilir sabit bir dil kullanabilmek adına kabul görmüş çalışmalar üzerinden, yapılan çalışmalar incelenerek İstanbul Büyükşehir Belediyesi tarafından üretilen sosyal konutlara yönelik gösterge seti oluşturulmaya çalışılmıştır. Yapılan çalışmalarda, yaşam kalitesinin oluşturulmasında kavramın birden fazla boyutlu olması, geniş bir alanı kapsaması ve farklı amaçlarla ortaya çıkması, bu amaç ve hedeflere bağlı olarak farklı göstergeler ve farklı değişkenler sistemi içerisinde açıklanmaya çalışıldığı anlaşılmaktadır. Çalışmada ortaya koyulan göstergeler, pilot anket soru formu ile birlikte hazırlanmış, pilot anket formunun güncellenmesi sırasında gösterge setide güncellenerek son haline getirilmiştir. Bu kapsamda, (1) yaşam durumu (kaliteli yaşam, gecekonduda hangi ilçede oturduğu, ne kadar süre yaşadı̆̆l, sosyal konutta ne kadar

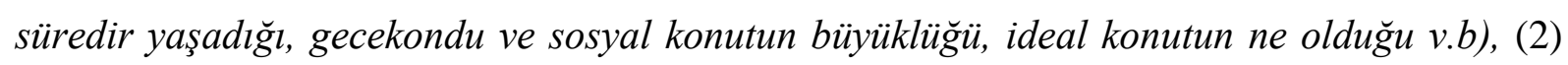
fiziksel faktörler (evin büyüklüğü, evin kullanışlılığl, eve arabaya / eşya taşıma kolayliğg, kendini evinde güvende hissetme, odaların sayısı, salon kullanışlılı̆̆l, odaların kullanışlılı̆̆g, mutfak kullanışlılı̆̆gl, tuvalet ve banyo kullanışlılı̆̆l, vb.), (3) çevresel faktörler (çevrenin düzenli ve bakımlı olması, hava kalitesi, şebeke suyu hizmeti, kanalizasyon hizmeti, sokak levhaları ve dış kapı numaralandırma hizmetleri, vb.), (4) sosyal ilişkilere yönelik karşılaştırmalar (komşuluk ilişkileri, yardımlaşma, komşulardan ufak tefek eşya ödünç alma ve verme, akrabalarla görüşme sıklı̆̆g, esnaflarla tanışıklık), (5) hizmetlere erişim (İşyerine yakınlık ve ulaşım süresi, okula yakınlık ve ulaşım süresi, çocukların okul eğitimi dışında özel kurs alma imkânları, să̆lık ocă̆ına yakınlık ve ulaşım süresi, hastaneye yakınlık ve ulaşım süresi, pazara yakınlık ve ulaşım süresi, toplu taşıma hizmeti vb.), (6) ekonomik faktörler (ekonomik durum, ekstra iş imkânları (bebek bakımı, tamirat, ev temizliği vb.), alışveriş yapılan ürün fiyatlarının uygunluğu, borçsuz yaşama, fatura giderleri vb.), (7) genele yönelik memnuniyet (sosyal konuttaki yaşantıdan genel memnuniyet, belediyenin hizmetlerinden memnuniyet, sosyal konuta taşınmakla ekonomik açıdan kazançlı olup olmama durumu) başlıklarından oluşan 7 temel kategori ve bu kategoriler altında yer alan toplam 80 gösterge belirlenmiştir.

Anket araştırmasının saha çalışması öncesinde anketör ekibine 1 günlük eğitim programı uygulanmıştır. Eğitim programı kapsamında anketörlere araştırma konusuyla ilgili bilgi verilmiş, sahada kullanılacak dokümanlar tanıtılmış, anket uygulaması yapılacak konut alanına erişim ile görüşme yapılacak hane ve kişilerin belirlenmesinde izlenecek yöntemler açıklanmış, 
anket föyü detaylı olarak aktarılmış ve anket uygulaması esnasında dikkat edilecek hususlar vurgulanmıştır.

Saha çalışmasında görev alan 5'i kız, 4'ü erkek olmak üzere toplam 9 anketör, ekipler halinde 506 adet anket görüşmelerini gerçekleştirmiştir. Ayrıca, SPSS ile analizi yapılan anketin güvenirlilik testi için, anket çalışmasında her sorunun diğer sorularla korelâsyonları ele alınmış ve güvenirlilik katsayısı hesaplanmıştır. Ölçeğin güvenilirliğine ve homojenliğine kanıt sağlamak amacıyla SPSS programı yardımıyla Cra katsayısı, yani genel güvenilirlik katsayısı hesaplanmış ve $\mathrm{Cr} \alpha=0.958$ bulunmuştur. Bu değer Güvenilirlik Skalası açısından yüksek bir değerdir ve ankette kullanılan ölçeğin “yüksek derecede güvenilir” olduğunu ifade etmektedir.

\section{BULGULAR VE DEĞERLENDİRME}

\subsection{Bulgular}

Araştırma kapsamında ankete katılan katılımcıların yaşları, cinsiyetleri, medeni durumları, eğitim durumları, doğum yerleri, meslekleri, sosyal güvence durumları, aylık ortalama gelirleri gibi temel özelliklerine ilişkin bilgiler edinilmiştir. Katılımcıların genel bilgilerini ve memnuniyet düzeyini tanımlamak için faktör, çapraz ve mean analizleri kullanılmıştır.

Buna göre, ankete katılanların yarısına yakını 36 ile 55 yaş aralığında, yaklaşık yarısı Karadeniz Bölgesi'nden göç etmiş hane halklarından oluşmaktadır. Katılımcıların yarısından fazlası ilköğretim ve ortaokul mezunu, yarıdan fazlasının tek kişinin çalışmasıyla, yaklaşık dörtte birinde ise iki kişinin çalışmasıyla geçimin sağlandığı ortaya çıkmıştır. Katılımcıların yarısından fazlası $1000 \mathrm{TL}$ ile $2500 \mathrm{TL}$ arasında bir gelire sahiptir. $1000 \mathrm{TL}$ ile $1500 \mathrm{TL}$ arasında ücret ile geçinen aile sayısı en fazladır. Katılımcılar kaliteli yaşamın, çoğunlukla güvenli (\%22.3), geçim zorluğu olmayan (\%20.9), sağl1k (\%14.7) ve sosyal imkânları iyi olan (\%11.2) bir kentte yaşamak olduğunu ifade etmişlerdir. Katılımcıların çoğunluğuna göre ideal konut, bahçeli ve tek katlı, merkeze yakın, manzaralı ve ileride değer kazanacak bir yerde olmalıdır. Katılımcılar ağırlıklı olarak sosyal konut yaşantısından memnun ve yaklaşık yarısı belediyenin hizmetlerinden genel olarak memnun olduklarını ifade etmiştir. Katılımcılardan ekonomik olarak kazançlı çıktığını düşünenler ile kazançlı çıkmadığını düşünenler ağırlıklı olarak hemen hemen aynı oranda bulunmaktadır. Katılımcılar yaşadıkları konutta en fazla \%33.5 oranında komşuluk, \%17.0 oranında yeşil alan miktarı, \%9.1 oranında ulaşım konusunda eksiklik çektiklerini belirtmişlerdir.

Fiziksel faktörlerde tercih ve genel eğilim sosyal konut yönündedir. Fiziksel faktörlere yönelik tercihlerde, binanın engellilere uygunluğu faktörü haricinde diğer faktörlerde sosyal konutun 
daha iyi olduğu belirtilmiştir. Fiziksel faktörlerde genel itibariyle az da olsa bir iyileşmeden bahsedilebilir.

Çevresel faktörlerde tercih ve genel eğilim sosyal konut yönündedir. Çevresel faktörlere yönelik tercihlerde, çevrenin engellilere uygunluğu faktörü haricinde diğer faktörlerde sosyal konutun daha iyi olduğu belirtilmiştir. Çevresel faktörlerde genel bir iyileşmeden söz edilebilir.

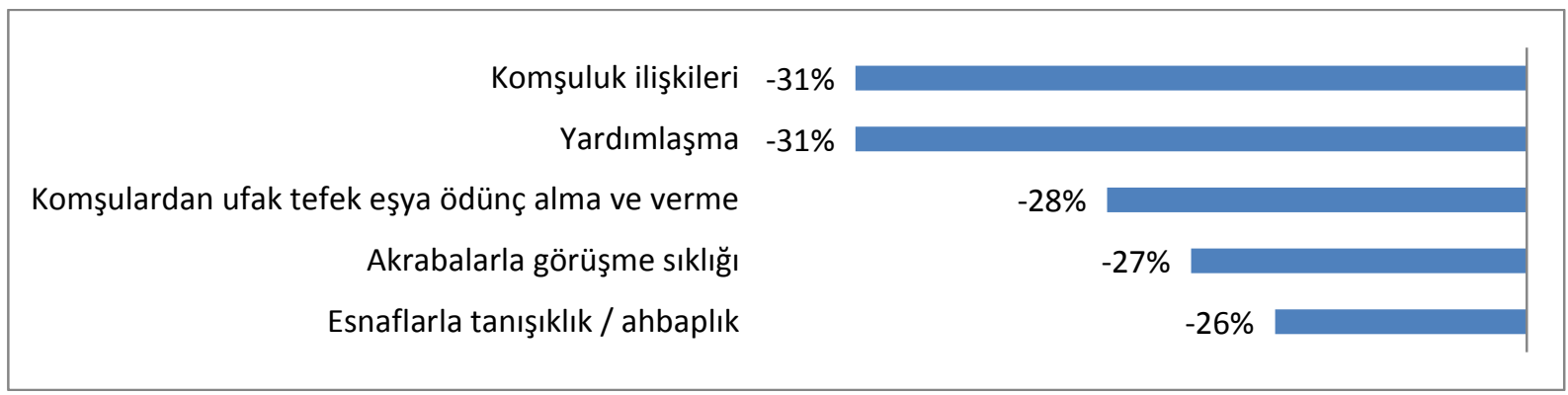

Şekil 3. Sosyal faktörlere göre konut tercihleri

Şekil 3'te sosyal faktörlere göre konut tercihleri gösterilmektedir. Şekil 3'te görüldüğü üzere, sosyal ilişkilere yönelik faktörlerde tercih ve genel eğilim gecekondu yönündedir. Sosyal ilişkilere yönelik tercihlerde faktörlerin tamamında gecekondu yaşamının daha iyi olduğu belirtilmiştir. Sosyal faktörlerde iyileşmeye yönelik herhangi bir durum olmadığı belirtilebilir. Hizmetlere erişimde tercih ve genel eğilim sosyal konut yönündedir. Hizmet faktörlerine yönelik tercihlerde, hastane, eğlence ve kültürel alanlara yakınlık ve dükkân ve market gibi alışveriş imkânları faktörleri haricinde diğer faktörlerde sosyal konutun daha iyi olduğu belirtilmiştir. Hizmet faktörlerinde bazı alanlarda iyileşme gözlemlenirken bazı faktörlerde hizmetin yeterince iyileşmediği söylenebilir.

\section{Ekonomik durumunuz}

Ekstra iş imkânları (bebek bakımı, tamirat, ev.. Alışveriş yaptığınız ürün fiyatlarının uygunluğu

Borçsuz yaşama
Fatura giderleri (ısınma, su, elektrik)
Eğitim masrafları
Esnaflardan veresiye alışveriş imkânı
Devletin ekonomik yardımı

Şekil 4. Ekonomik faktörlere göre konut tercihleri

Şekil 4'te ekonomik faktörlere göre konut tercihleri gösterilmektedir. Şekil 4'te görüldüğü üzere, Ekonomik faktörlere yönelik tercihlerde, devletin ekonomik yardımı faktörü haricinde diğer faktörlerde gecekondu yaşamının daha iyi olduğu belirtilmiştir. Ekonomik faktörlerde genel olarak iyileşme olmadığ belirtilebilir. 
Araştırma sonuçları doğrultusunda temel göstergelerden, fiziksel, çevresel, hizmetlere erişim ve genel memnuniyetle ilgili genel itibariyle ilerleme olduğu, sosyal ilişkilerde ve ekonomik durumda ise gerileme olduğu görülmektedir.

\subsection{Değerlendirme}

Gecekondu alanlarında yapılan çalışmalar, daha iyi işleyen bir sisteme sahip sosyal konut üretmek amacı taşımaktadır [45]. Bir komşuluğun yıkılması, değişen şehirlerde önemli bir neticedir [46]. Çevredeki akraba ve arkadaş sayısı sosyal ilişkilerin varlığı için objektif bir göstergedir [47-48].

Aynı memleketten olma, hemşerilik ilişkisi vb. gecekondulaşma sürecinde oldukça önemlidir. $\mathrm{Bu}$ çalışma sonucunda, sosyal konut üretimi sürecinde mevcut hemşerilik ilişkisi ve sosyal konut üretimi sonucunda ne olacağı ile ilgili belediye tarafından ön çalışmaların yapılmadığı tespit edilmiştir. Hane halklarının demografik özelliklerinin belediye tarafından dönüşüm çalışmalarında değerlendirilmediği de çalışmanın sonucunda ortaya çıkmıştır.

Clampet-Lundquist' in yaptığı çalışmada [49], Amerika'da birçok insan önceki konutuna yakın yerlere taşınmak istemektedir. Kleinhans [29], Gaumer ve diğ. [50], Cavalheiro [3], İçli [51] çalışmalarında, komşuluk ilişkileri ile ilgili toplumsal etkileşimlerin eskiye oranla azaldığını ortaya koymuştur. Bolt ve diğ. [52], Phillips ve Harrison [53] yaptıkları çalışmalarda, gecekondu tasfiyesi ile sadece evlerin değil, sosyal ilişkilerinde yıkıldığını belirtmiştir. Araştırma sonuçlarında, sosyal ilişkilere yönelik faktörlerle ilgili algılamalar incelendiğinde, diğer çalışmalara benzer şekilde, sosyal ilişkilerin gecekondu yaşamında çok daha iyi olduğu, sosyal konuta taşındıktan sonra kötüleştiği ortaya çıkmıştır. Buna göre, sosyal konuta taşınmak, gecekondu sahiplerinin sosyal ilişkileri açısından yapıcı olmaktan ziyade yıkıcı bir faaliyete dönüşmektedir. Yerdeğiştirme, sosyal ilişkilerin bozulmasıyla birlikte, taşınılan sosyal konuta aidiyet duygusunu artırmaktan ziyade geçmişe olan bağlılıkları artırıcı bir rol üstlenmiştir.

Katılımcılar sosyal konutun en olumlu tarafını en fazla \%54.9 oranında bina kalitesi olduğunu ifade etmişlerdir. \%24.5 oranında katılımcı ise fark olmadığını belirtmiştir. Açıkçası, fiziksel açıdan yaşam koşullarının iyileştiğini belirtebilmek için en azından bina kalitesi ile ilgili olumlu yaklaşımın daha fazla olması gerekmekte ve bina kalitesinde birtakım iyileştirmelere gidilmesi gerektiği ortaya çıkmaktadır.

Yaşam kalitesinin en temel unsuru, şüphesiz gelir düzeyidir. Gelir düzeyi, ailelerin ihtiyaçlarını karşılama düzeylerini belirlemenin yanı sıra sağlık, eğitim, sosyal etkileşim, konut, serbest zaman ve genel yaşam tarzı koşulları ile de doğrudan ilgilidir [54]. Gelirin toplumdaki sınıflar arasında dağılımı dengeli olduğu sürece kentsel yaşam kalitesi de yükselir [11]. 
Bu çalışmada, katılımcıların yarısından fazlasında aileler geçimini tek başına karşılamaktadır. Araştırmada, yaşam koşullarındaki değişikliklerin algılanmasında gelirin etkisi olduğu görülmektedir. Gelir düzeyinin artmasıyla, fiziksel, çevresel, hizmetlere erişim ve ekonomik faktörlerde iyileşmenin daha fazla olduğu belirtilmiştir. Gelirin azaldığı durumlarda, memnuniyetinde azaldığı görülmektedir. Sosyal konut üretiminin bir amacı da işsizliğin azaltılarak işgücünü artırmak ve böylece yaşam koşullarının iyileşmesine olanak sağlamak olmalıdır. Belediye tarafından yaşam kalitesinin iyileştirilmesi hedefiyle yapılan sosyal konutlar bu anlamda hedefe ulaşamamış görünmektedir. Buna göre, belediyenin bundan sonra yapacağı sosyal konut faaliyetlerinde gelir artırıcı tedbirleri alması gerekmektedir. Bu sebeple, hane halklarının ekonomik seviyelerini artırıcı tedbirlerin sosyal belediyecilik çerçevesinde değerlendirilerek alınması gerekmektedir.

Bu çalışmada, gecekonduda yaşanılan sürenin yaşam kalitesindeki algılardaki değişikliklerde önemli olduğu ortaya çıkmıştır. 10 yıl ve altı süre gecekonduda yaşayanların sosyal konut hayatından daha fazla memnun ve yaşamlarındaki kalitenin daha fazla arttığı sonucu çıkmıştır. Gecekonduda yaşanılan süre artıkça, sosyal konuttaki yaşamdan memnuniyet azalmaktadır. Bu sebeple, sosyal konuttaki yaşama alışma süresini azaltmak amacıyla, Belediye tarafından aidiyet duygusunu güçlendirici çalışmalar yapılmalı ve sosyal konuttaki memnuniyetin artırılması sağlanmalıdır.

\section{SONUÇ}

$\mathrm{Bu}$ çalışmanın amacı, yaşam kalitesinin yükseltilmesi ve sosyal konut tahsisi arasındaki ilişkinin çözümlenmesiyle, sosyal konut tahsisinin gecekondu sakinlerinin yaşam kalitelerine katkı sağlayacak özelliklerinin belirlenmesi ve bu özelliklerin üretilecek sosyal konut alanlarında uygulanmasıdır. Bu amaç doğrultusunda, yaşam kalitesinin demografik özelliklere göre nasıl algılandığı ve yaşam kalitesindeki değişikliklerin pozitif yönde olması bağlamında çözümlenmesi çalışmanın başlıca hedefleri olmuştur.

Sosyal konut projelerinin, kent sakinlerine sağlayacağı yarar, kentin bütününe yansıyacağından, bu yararın bütüncül bir şekilde ele alınması gerekmektedir. Fiziksel açıdan bir miktar tatminkâr olan sosyal konut uygulamalarında, sosyal ilişkileri artırıcı bir takım çalışmaların yapılması kaçınılmazdır. $\mathrm{Bu}$ çalışmalar yapılmadığı müddetçe, sorunların çözümü tam olarak gerçekleşememiş, sosyal amaçlar hedefine ulaşamamış olacaktır. Ailelerin özelliklerinin bilinmemesi, yaşam kalitesi ile ilgili algıları kötü yönde etkilemektedir. Sosyal konut uygulamalarında, ailelerin sosyal ve demografik özellikleri, istek ve ihtiyaçları dikkate 
alınmalıdır. Çünkü farklı özelliklere sahip birey ve ailelerin yaşam kalitesi algılamaları farklılık göstermektedir.

Yerel yönetimler, yaşam kalitesi çalışmalarında oldukça önemli bir yere sahiptir. Yerel yönetimlerce gecekondu tasfiyesine dayalı üretilecek sosyal konutlarda yaşam kalitesinin artırılması amacıyla her bir ölçeğe göre göstergeler belirlenmeli, üniversiteler, sendikalar gibi diğer kuruluşlarla işbirliği yaparak bu göstergelere ilişkin bütüncül yaklaşım sergilenmeli ve her anlamda yaşam koşullarının iyileştirilmesine çalışılmalıdır. İstanbul'da belediye eliyle üretilen sosyal konutlarla ilgili belediye tarafından belirlenmiş yaşam kalitesi göstergeleri bulunmamaktadır. Özellikle tasfiye yapılacak alanlarda, demografik yapının da dikkate alınarak, oluşturulacak göstergelerle tekrarlı çalışmalar yapılmalıdır.

Bir defa uygulanan bu çalışma, statik bir durumu ifade ettiğinden, bu ve buna benzer çalışmalar gelişmiş ülkelerde olduğu gibi belirli aralıklarla tekrarlanmalı, bilgi sistemi oluşturulmalı, bütün veriler bu sisteme girilmeli, yaşam kalitesinde meydana gelen değişiklikler izlenmeli ve değerlendirilmelidir.

Çalışmanın teoriye ve uygulamaya en önemli katkılarından biri, hedef kitle özelliklerine göre sosyal belediyecilik anlayışının sosyal konut uygulamalarına yansıması gerektiğini ortaya koymasıdır. Hedef kitlenin demografik özellikleri kadar, öncesinde yaşamış oldukları konutun özellikleri de oldukça önemlidir. Bu özellikler fiziksel olabildiği gibi, sosyal, ekonomik, hizmetlerin algılanma biçimi vs. şeklinde de olabilir. Sosyal konut üretiminde amaç, hane halklarının daha sağlıklı ve kaliteli bir çevrede mutlu yaşam üretmek olduğundan, bu çalışma sonucuna göre, bu hedeflerin hedef kitlenin özellikleri bilinmeden gerçekleştirilmesi mümkün olamamaktadır. Geçmişten günümüze devam eden çarpık kentleşme ile beraber ortaya çıkan konut sorununa ilişkin çözümler ve uygulamalar gelecekte de devam edecektir. Bu sorunların çözümü ve kurumların başarısı, katılımcılar ve aktörlerin bir araya gelerek ve mevcut koşullar göz önünde bulundurularak yapılmasından geçmektedir.

\section{KAYNAKLAR}

[1] N. R. Zainal, G. Kaur, N. A. Ahmad, J. M. Khalili, Housing Conditions and Quality of Life of the Urban Poor in Malaysia, Social and Behavioral Sciences, 50 (2012) 827-838.

[2] D.K. Jha, V.K. Tripathi, Quality of life in slums of Varanasi city: a comparative study, Transactions, 36 (2) (2014) 171-183.

[3] C. Cavalheiro, A. Abiko, Evaluating slum (favela) resettlements : the case of the Serra do Mar Project, Sao Paulo, Brazil, Habitat International, 49 (2015) 340-348.

[4] UN-HABITAT, World Cities Report. (United Nations Human Settlements Programme, Nairobi, 2016). 
[5] K. Ören, H. Yüksel, Türkiye'de konut sorunu ve temel dinamikleri, SDÜ Sosyal Bilimler Enstitüsü Dergisi, 18 (2) (2013) 47-84.

[6] M. Şeker, İstanbul'da Yaşam Kalitesi Araştırması. (İstanbul Ticaret Odası Yayınları, İstanbul, Yayın No: 2010-103, 2011).

[7] B. Koyuncu, Yüksek Lisans Tezi, Marmara Üniversitesi, Sosyal Bilimler Enstitüsü, İstanbul, (2011).

[8] A. Booth, H. Camp, Housing Relocation and Family Social Integration Patterns, Journal of American Institute of Planners, 40 (2) (2007) 124-128.

[9] Z.A.G. Üçer, Doktora Tezi, Gazi Üniversitesi, Fen Bilimleri Enstitüsü, Ankara (2009).

[10] M.A. Karasu, Türkiye'de konut sorununun çözümünde farklı bir yaklaşım; belediye-toplu konut idaresi-konut kooperatifleri işbirliği modeli, Ekonomik ve Sosyal Araştırmalar Dergisi, 1 (2005) 56-87.

[11] P.S. Yavuzçehre, ve S.E. Torlak, Kentsel yaşam kalitesi ve belediyeler: Denizli Karşlyaka mahallesi örneği, SDÜ Sosyal Bilimler Enstitüsü Dergisi, 2 (4) (2006) 184-207.

[12] E.K. Koramaz, Doktora Tezi, İstanbul Teknik Üniversitesi, Fen Bilimleri Enstitüsü, İstanbul, (2010).

[13] H.H. Soliman, A.F. Alzamil, N.I. Alsharqawi, H.M. Hegazy, M.A. Almeshaal, Families' Satisfaction With Public Housing in Saudi Arabia and Its Effect on the Quality of Their Lives, Journal of Social Service Research, 41 (2015) 385-397.

[14] G.Ö. Ersin, Yüksek Lisans Tezi, Mimar Sinan Güzel Sanatlar Üniversitesi, Fen Bilimleri Enstitüsü, İstanbul (2012).

[15] S.A.M. El Ariane, Ph.D. Thesis, Cairo University, Egypt (2012).

[16] C.J. Andrews, Analyzing Quality of Place, Environment and Planning B: Planning and Design, 28 (2) (2001) 201-217.

[17] M. Pacione, Space Preferences, Locational Decisions, and the Dispersal of Civil Servants from London, Environment and Planning A, 14 (3) (1982) 323-333.

[18] N.B. Wish, Are we really measuring quality of life, American Journal of Economics and Sociology, 45 (1) (1986) 93-99.

[19] D. Felce, J. Perry, Quality of life: its definition and measurement, Research in Developmental Disabilities, 16 (1) (1995) 51-74.

[20] R.A. Cummins, in Urban Quality of Life, Critical Issues and Options, eds. Lim Lan Yuan, Belinda Yuen, Christine Low, p. 20-33 (National University of Singapore Press, Singapore, 1999).

[21] M. Rapley, Quality of life research: a critical introduction (SAGE Publications, London, 2003).

[22] Y.J. Lee, Subjective Quality of Life Measurement in Taipei, Building and Environment, 43 (7) (2008) 1205-1215.

[23] I. Van Kamp, K. Leidelmeijer, G. Marsman, A. de Hollander, Urban environmental quality and human well-being: towards a conceptual framework and demarcation of concepts: a literature study, Landscape and Urban Planning, 65 (1-2) (2003) 5-18.

[24] Kalkınma Bakanlığı, Onuncu kalkınma planı (2014-2018). (Kalkınma Bakanlığı, Ankara, 2013). 
[25] A. Bodur, Yüksek Lisans Tezi, Bahçeşehir Üniversitesi, Fen Bilimleri Enstitüsü, İstanbul (2012).

[26] M. Kara, Doktora Tezi, Süleyman Demirel Üniversitesi, Sosyal Bilimler Enstitüsü, Isparta (2012).

[27] M. Akdemir, Gecekondu Islah Projeleri Uygulamaları ve Hazine Taşınmaz Malları İe Illişkileri. (Milli Emlak Genel Müdürlügüü, Ankara, 1998).

[28] Y. Aksoylu, Kent Gecekondulularının Sosyal Dayanışma Bağları ve Yerel Yönetimle Etkileşimleri. (Bayındırlık ve İskan Bakanlığı, Ankara, 1987).

[29] R. Kleinhans, Displaced but still moving upwards in the housing career? Implications of Forced Residential Relocation in the Netherlands, Housing Studies, 18 (4) (2003) 473499.

[30] E. Van Beckhoven, R. Van Kempen, Social Effects of Urban Restructuring: A Case Study in Amsterdam and Utrect, The Netherlands, Housing Studies, 18 (6) (2003) 853-875.

[31] E. Bayraktar, Kentsel dönüşüm uygulamalarının sosyal politikalara etkisi, Çerçeve Dergisi, 49 (2009) 16-22.

[32] C. Reinprecht, C. Lévy-Vroelant, F. Wassemberg, in Social Housing in Europe II A Review of Policies and Outcomes, eds. K. Scanlon, C. Whitehead, pp. 31-46 (London School of Economics and Political Science, London, 2008).

[33] N.F. Kundurac1, Dünyada ve Türkiye’de Sosyal Konut Uygulamaları, Çağdaş Yerel Yönetimler, 22 (3) (2013) 53-77.

[34] S. Kutsal, Yüksek Lisans Tezi, Yıldız Teknik Üniversitesi, Fen Bilimleri Enstitüsü, İstanbul (2012).

[35] C. Tutin, Social Housing: Another French Exception?. The Central and East European Workshop on Social Housing, organised by the Metropolitan Research Institute, Budapest, Hungary: October 6-7 (2008).

[36] C. Whitehead, K. Scanlon, Social Housing in Europe. (London School of Economics and Political Science, London, 2007).

[37] M. Blanc, The Impact of Social Mix Policies in France, Housing Studies, 25 (2) (2010) 257-272.

[38] S. Mutlu, Yüksek Lisans Tezi, Ankara Üniversitesi, Sosyal Bilimler Enstitüsü, Ankara, (2007).

[39] Y. Alkışer, H. Yürekli, Türkiye'de “Devlet Konutu”nun dünü, bugünü, yarını. İTÜ Dergisi/A Mimarlık, Planlama, Tasarım, 3 (1) (2004) 63-74.

[40] O. Taşar, S. Çevik, Sosyal konut ve konut sektörüne devlet müdahalesi: Avrupa ülkeleri ve Türkiye, Aksaray Üniversitesi İİBF Dergisi, 1(2) (2009) 133-163.

[41] P. Çağlayan, Yüksek Lisans Tezi, Mimar Sinan Güzel Sanatlar Üniversitesi, Fen Bilimleri Enstitüsü, İstanbul (2011).

[42] M. Gür, Yüksek Lisans Tezi, Uludağ Üniversitesi, Fen Bilimleri Enstitüsü, Bursa (2009).

[43] İBB Mesken Müdürlüğü, Faaliyet raporu. (İstanbul Büyükşehir Belediyesi, İstanbul, 2013).

[44] M. Sencer, Y. Irmak, Toplumbilimlerinde Yöntem. (Say Kitap, İstanbul, 1984). 
[45] K. Kintrea, Policies and programmes for disadvantaged neighbourhoods: recent english experience, Housing Studies, 22 (2) (2007) 261-282.

[46] F. Eke, Gecekondu alanlarının değerlendirilmesine ilişkin çözümler, Süleyman Demirel Üniversitesi İktisadi ve İdari Bilimler Fakültesi Dergisi, 5 (1) (2000) 43-54.

[47] H.D. Türkoğlu, F. Bölen, P.K. Baran, R.W. Marans, İstanbul'da yaşam kalitesinin ölçülmesi, İTÜ Dergisi, Mimarlık, Planlama, Tasarım, 7 (2) (2008) 103-113.

[48] A.G. Salleh, N. Badarulzaman, Quality of Life of Residents in Urban Neighbourhoods of Pulau Pinang, Malaysia, Journal of Construction in Developing Countries, 17 (2) (2012) 117-123.

[49] S. Clampet-Lundquist, HOPE VI relocation: moving to new neighbourhoods and building new ties, Housing Policy Debate, 15 (2) (2004) 415-447.

[50] E. Gaumer, A. Jacobowitz, J. Brooks-Gunn, Building Ties: The Social Networks of Affordable-Housing Resident, Cityscape: A Journal of Policy Development and Research, 16 (3) (2014) 47-68.

[51] G. İçli, Kentsel dönüşüme ilişkin sosyolojik bir değerlendirme - Denizli örneği, Sosyal ve Beşeri Bilimler Dergisi, 3 (1) (2011) 43-57.

[52] G. Bolt, D. Phillips, R. Van Kempen, Housing Policy, (De)segregation and Social Mixing: An International Perspective, Housing Studies, 25 (2) (2010) 129-135.

[53] D. Phillips, M. Harrison, Constructing an integrated society: historical lessons for tackling black and minority ethnic housing segregation in Britain, Housing Studies, 25 (2) (2010) 221-235.

[54] A. Aydıner Boylu, G. Terzioğlu, Ailelerin yaşam kalitesini etkileyen bazı objektif ve subjektif göstergelerin incelenmesi. H.Ü. İktisadi ve İdari Bilimler Fakültesi Dergisi, 26 (2) (2008) 1-27. 